\title{
Role of diatom-attached choanoflagellates of the genus Salpingoeca as pelagic bacterivores
}

\author{
Karel Šimek $^{1,2, *}$, Jan Jezbera ${ }^{1,2}$, Karel Horňák ${ }^{1,2}$, Jaroslav Vrba $^{1,2}$, Jaromír Sed'a ${ }^{1}$ \\ ${ }^{1}$ Hydrobiological Institute of the Academy of Sciences of the Czech Republic, and ${ }^{2}$ University of South Bohemia, \\ Faculty of Biological Sciences, Na sádkách 7, 37005 České Budějovice, Czech Republic
}

\begin{abstract}
We studied the ecological role of choanoflagellates of the genus Salpingoeca (possibly S. amphoridium) attached to the colonial diatoms Asterionella formosa and Fragilaria crotonensis in the Rímov reservoir (South Bohemia). The choanoflagellate was found only on these 2 species of diatoms ( 0 to 35 choanoflagellate cells per diatom colony). It is clearly identifiable in natural samples, and is a highly efficient planktonic bacterivore. In 2 field experiments (Expt 1 in June 2000 and Expt 2 in September 2002) we estimated in situ rates of bacterivory using fluorescently labeled bacteria (FLB) as tracers. There was a linear increase in the number of FLB per choanoflagellate during the first 30 min of incubation, with only 8 to $16 \%$ of individuals within the natural populations displaying no ingestion of FLB. Taxon-specific bacteria uptake rate of Salpingoeca spp. was 35 to 65 bacteria cell $^{-1} \mathrm{~h}^{-1}$. In Expt 2, by manipulating phosphorus (P) and organic carbon availability (glucose), we also examined how alga host and bacterial prey abundances can affect the dynamics of Salpingoeca and of other bacterivorous heterotrophic nanoflagellates (HNF). P additions increased the growth of F. crotonensis and subsequently also that of the attached Salpingoeca sp. In contrast, glucose addition produced a marked development of small, free-swimming chrysomonads which competed with the choanoflagellate for the bacteria. Overall, across all experimental treatments Salpingoeca spp. grazing accounted for 11 to $64 \%$ of the total protistan grazing and for 6 to $49 \%$ of the daily removal rate of the bacterial standing stock. Our data indicate that given a sufficient abundance of suitable host algae, which possibly provide a refuge from potential grazers, and efficient grazing of freeswimming HNF by zooplankton, this single choanoflagellate taxon can temporarily constitute the most important pelagic bacterivore in the reservoir.
\end{abstract}

KEY WORDS: Reservoir · Microbial food webs · Protistan bacterivory · Bacterioplankton · Grazinginduced mortality $\cdot$ Choanoflagellates $\cdot$ Ciliates

Resale or republication not permitted without written consent of the publisher

\section{INTRODUCTION}

Heterotrophic nanoflagellates (HNF) are recognized as the major consumers of bacteria and important nutrient remineralizers in most aquatic systems (e.g. Sherr et al. 1983, Caron \& Dennet 1986, Sanders et al. 1989). For natural freshwater systems, the major forces which regulate the biomass and growth rate of HNF communities have been well studied (e.g. Berninger et al. 1991, Weisse 1991, Gasol et al. 1995); however, very little is known about the taxonomic composition of HNF communities and the feeding ecology of individual HNF species in situ (Arndt et al. 2000, Weisse
2002). This is primarily due to the lack of discernable species-specific morphological traits that would enable identification of HNF species by epifluorescence microscopy. Recent techniques, such as molecular probes, allow unequivocal identification of a single HNF taxon, but as yet these are available for only a limited number of species (e.g. Lim et al. 1999).

Usually HNF communities in the plankton are described by bulk parameters such as total biomass, numbers and bacterivory. Such descriptors involve a good deal of averaging or 'lumping'. For instance, only remotely related, morphologically similar species or groups of smaller HNF are frequently grouped 
together into functional guilds such as 'bacterivorous HNF' (e.g. Sanders et al. 1989, Berninger et al. 1991, Dolan \& Gallegos 1991). However, less numerous but larger forms of HNF often comprise the major part of HNF biomass (Mathes \& Arndt 1994), and these have little or no grazing impact on the bacterioplankton (e.g. Šimek et al. 1997, Cleven \& Weisse 2001). In addition, similarly sized, presumably bacterivorous HNF show large taxon-specific differences in feeding rates and in situ niche-partitioning has been demonstrated for some of them (e.g. Sanders 1991, Arndt et al. 2000). Thus, natural HNF assemblages consist of flagellate species exhibiting a wide array of feeding strategies and preferences (Sanders 1991, Arndt et al. 2000, Sherr \& Sherr 2002), and possessing different capacity for preying on bacterial particles. Only recently has HNF taxon-specific bacterivory been measured in situ, but here again only larger taxonomic entities or ecological guilds were characterized (Hwang \& Heath 1997, Šimek et al. 1997, Cleven \& Weisse 2001).

A commonly used method for estimating bacterivory based on short-term uptake measurements of fluorescently labeled bacteria (FLB; Sherr \& Sherr 1993) can detect species-specific differences in protistan bacterivory. The advantage of the technique is that it allows analysis of the food-vacuole content of an individual bacterial predator, thus also providing information on the variability of uptake rates within a given population. Some authors have suggested the possibility of a large statistical error inherent in the FLB method when applied to assessment of bulk HNF bacterivory (Cho et al. 2000, Cleven \& Weisse 2001, Weisse 2002). However, a significant portion of the variability in uptake data is probably due to the presence of a variable fraction of non-bacterivores among HNF species (e.g. Bratvold et al. 2000, Cleven \& Weisse 2001), which may reflect interspecific variation in different HNF grouped together to estimate the bulk community bacterivory. For methodical reasons, unequivocal identification of planktonic HNF species or even genera with an epifluorescent microscope still remains difficult (e.g. Arndt et al. 2000).

Several studies have reported high taxon-specific bacterivory for the morphologically distinctive choanoflagellates often found attached to diatom colonies (Sanders et al. 1989, Vaqué \& Pace 1992, Carrias et al. 1996, Hwang \& Heath 1997, Šimek et al. 1997). The present study focuses on these flagellates. We have attempted to determine the ecological role of the genus Salpingoeca, which comprises possibly the most important and neglected, substratum-attached bacterivorous choanoflagellates. Salpingoeca spp. inhabit almost exclusively colonies of the planktonic diatoms Asterionella formosa and Fragillaria crotonensis. By means of 2 experiments in a freshwater reservoir, we examined taxon-specific bacterivory in Salpingoeca spp., their ecological role relative to other HNF, and natural variability in their FLB uptake rates. Expt 1 was conducted during a period of a high abundance of $A$. formosa (June 2000), while during Expt 2 F. crotonensis dominated in the phytoplankton biomass (September 2002). Additionally, by manipulating phosphorus and organic carbon availability in Expt 2, we examined if/how their development on an alga host and abundance of bacterial prey can affect the dynamics of Salpingoeca spp.

\section{MATERIALS AND METHODS}

Study site and experimental design. We ran 2 experiments in the canyon-shaped Rímov reservoir (South Bohemia, $470 \mathrm{~m}$ above see level; area $=2.06 \mathrm{~km}^{2}$; volume $=34.5 \times 10^{6} \mathrm{~m}^{3}$; length $=13.5 \mathrm{~km}$; maximum depth $=43 \mathrm{~m}_{\text {; }}$ mean depth $=16.5 \mathrm{~m}$; mean retention time $=100 \mathrm{~d}$; dimictic, meso-eutrophic) during periods when colonial diatoms of the genera Asterionella and Fragilaria, which comprise the substratum for choanoflagellate attachment, are abundant.

Expt 1 (described in detail in Šimek et al. 2003) was designed to determine the major factors shaping bacterioplankton community composition in different parts of the Rímov reservoir. The experiment was conducted during the late clear water phase (12 to 16 June 2000, water temperature $23^{\circ} \mathrm{C}$ ), characterized by an increasing concentration of colonial diatoms dominated by Asterionella formosa. Water was collected from a depth of $0.5 \mathrm{~m}$ at a sampling site located about $250 \mathrm{~m}$ from the reservoir dam. This study presents only the data from unfiltered samples incubated in dialysis bags in the dam area, i.e. from untreated samples containing the original concentrations of diatom colonies and zooplankton. This community grew for $4 \mathrm{~d}$ in duplicate dialysis tubes ( 2 1 content, diameter $75 \mathrm{~mm}$, molecular weight cut-off 12000 to 16000 Da, Poly Labo); incubation was at the sampling site under in situ conditions of nutrient limitation: $2 \mu \mathrm{g} \mathrm{l}^{-1}$ of dissolved reactive phosphorus (DRP) and $11 \mu g \mathrm{l}^{-1}$ of total phosphorus (TP; for details of parameters of water chemistry see Šimek et al. 2003).

Expt 2 was conducted between 9 and 13 September 2002, during a period of high concentration of colonial diatoms dominated by Fragillaria crotonensis. Expt 2 was run in transparent $(\sim 80 \%$ of ambient light intensity) 501 polyethylene barrels (acid-soaked and washed several time with deonized water) filled with water from a depth of $0.5 \mathrm{~m}$ at the same sampling site as for Expt 1. The water used for Expt 2 was phosphorus (P)-limited (1.9 $\mu \mathrm{g} \mathrm{l}^{-1} \mathrm{DRP}$ and $\left.20 \mu \mathrm{g} \mathrm{l^{-1 }} \mathrm{TP}\right)$, but not nitrogen-limited $\left(\sim 1.5 \mathrm{mg}\right.$ total $\left.\mathrm{N}^{-1}\right)$. By manipulating 
$\mathrm{P}$ and organic carbon availability in the experimental barrels, we intended to differentially stimulate bacterial and diatom growth and subsequently that of freeswimming and particle-bound bacterivorous flagellates. Immediately after being filled with unfiltered reservoir water, selected barrels were amended by additions of either $\mathrm{KH}_{2} \mathrm{PO}_{4}$ (+ $\mathrm{P}$ treatment; final concentration of $62 \mu \mathrm{g} \mathrm{P}^{-1}$ ) or glucose (+ GLU treatment; final concentration of $2.5 \mathrm{mg} \mathrm{Cl}^{-1}$ ), or by a combination of both (+ P + GLU treatment). The contents of the barrels were thoroughly mixed, attached to a floating platform and incubated in situ for $4 \mathrm{~d}$ at the sampling site. The experimental design consisted of the following duplicate treatments: (1) whole-water sample taken directly from the reservoir; in contrast to treatments (2) to (5) which were incubated in barrels: (2) control, no treatment; (3) + P treatment; (4) + GLU treatment; and (5) + P + GLU treatment.

By subsampling 21 of experimental water at 0,48 and $96 \mathrm{~h}$, we monitored the following basic parameters in all 5 treatments: phosphorus, chlorophyll a $(\mathrm{chl} a)$ content, bacteria dynamics, colonial diatoms, diatomattached choanoflagellates, total HNF, ciliates, and bacterial grazing by the last 3 groups of protozoans.

Bacterial abundance and cell volume. Duplicate subsamples were fixed with formaldehyde (final concentration $=2 \% \mathrm{wt} / \mathrm{vol}$ ), and stained with DAPI (final concentration $=0.2 \% \mathrm{wt} / \mathrm{vol}$ ), and bacterial cells ( $>400$ sample ${ }^{-1}$ ) were enumerated by epifluorescence microscopy (Olympus BX-60). Between 400 and 600 DAPIstained bacterial cells were recorded at a magnification 1000 with an analog monochrome chargecoupled device (CCD) camera (Cohu) mounted on the microscope and processed with the semiautomatic image-analysis system LUCIA D (Lucia 3.52, resolution $750 \times 520$ pixels, 256 gray levels, Laboratory Imaging) Details of the image processing are given by Posch et al. (1997). Bacteria biomass was calculated according to the allometric relationship between cell volume and carbon content described by Norland (1993).

Protozoan abundance and bacterivory. To measure protozoan grazing on bacterioplankton, we used FLB (Sherr \& Sherr 1993) concentrated from the reservoir water. The experimental protocol is detailed and discussed in Šimek et al. (1997, 2000). Briefly, in Expt 1 FLB uptake measurements were run for the unfiltered samples in the dam area, and in Expt 2 in the reservoir water and in each of the barrels at times $t_{0}, t_{48}$ and $t_{96}$ h. Flagellate and ciliate uptake rates were determined in the same treatment in which the number of FLB added constituted 5 to $15 \%$ of in situ bacterial abundances. We determined ciliate grazing rates in a 5 to 15 min time series of subsamples, and flagellate grazing rates in a 10 to $30 \mathrm{~min}$ time series. Time zero was also examined to avoid potential biases due to attachment of non-ingested tracers on protozoan surfaces. Usually 5 to $10 \mathrm{ml}$ (flagellates) or $20 \mathrm{ml}$ (ciliates) subsamples were stained with DAPI, filtered through $1 \mu \mathrm{m}$ black Poretics filters, and examined by epifluorescence microscopy (Olympus, AX70 PROVIS, magnification 1000); protist counts were made and uptake rates analyzed (for details see Šimek et al. 2000). Nonpigmented, total HNF, HNF of the genus Salpingoeca attached to diatoms (Asterionella formosa, Fragilaria crotonensis) and plastidic flagellates were differentiated. At least 50 ciliates and 100 to 200 flagellates were examined for FLB ingestion in each sample. To estimate total protozoan grazing, we multiplied the average uptake rates of ciliates and flagellates by their in situ abundance.

Abundance of colonial diatoms, of diatom-attached choanoflagellates and their bacterivory. To estimate the quantitative importance and role of the diatombound choanoflagellates of the genus Salpingoeca to total protistan bacterivory, our standard counting protocols and FLB uptake estimates were partly modified. The abundance of diatom colonies was enumerated in 10 to $20 \mathrm{ml}$ DAPI-stained subsamples filtered onto $2 \mu \mathrm{m}$ black Poretics filters at $400 \times$ magnification (Olympus, AX70 PROVIS), and the number of single diatom cells per colony of Asterionella formosa or Fragilaria crotonensis was also recorded. Then, in the same preparation but at $1000 \times$ magnification, the numbers of Salpingoeca spp. attached to at least 100 diatom colonies (for example see Fig. 1) of $A$. formosa and $F$. crotonensis were counted. Uptake rates were calculated based on examination of 100 to 508 choanoflagellate cells per sample (see examples in Figs. 2 \& 3).

Flagellate identification. The choanoflagellate cells on Asterionella formosa or Fragillaria crotonensis are flask-shaped, sessile with no visible peduncle and thecate. The protoplast bears a well-developed collar of tentacles and a long single flagellum (Fig. 1B). These features are characteristic of the genus Salpingoeca and the general appearance is similar to that of $S$. amphoridium. However, without further electron microscopical analysis identification was not certain, and the species will therefore be referred to herein as Salpingoeca sp. All cells seemed to belong to the same species and identification to the genus level and tentative identification to the species level of $S$. amphoridium was made by B.S. C. Leadbeater (University of Birmingham, UK), based on examination of several samples. Mean cell dimensions $( \pm \mathrm{SD})$, based on examination of 100 formaldehyde-fixed diatom-bound cells of Salpingoeca sp., were as follows: length, $5.4 \pm$ $1.3 \mu \mathrm{m}$; width, $3.9 \pm 1.1 \mu \mathrm{m}_{\text {; volume, }} 44 \pm 32 \mu \mathrm{m}^{3}$.

Zooplankton. At the beginning of Expt 1, we concentrated zooplankton $>40 \mu \mathrm{m}$ from a duplicate $10 \mathrm{l}$ 
unfiltered water sample; at the end of the experiment, the whole volume of water remaining in the dialysis bags ( 1 l) was concentrated and zooplankton composition was analyzed (for details of the experimental design see Šimek et al. 2003). A modified approach was applied in Expt 2. The initial crustacean and rotifer densities were estimated on the basis of analysis of 3 parallel 501 barrels filled with the water (see above the design of Expt 2), which were harvested by filtration on a $40 \mu \mathrm{m}$ sieve at $t_{0}$. This yielded an estimation of initial zooplankton density, including variability. The final zooplankton densities were estimated from the volume of water remaining in each barrel ( 42 l) at $t_{96}$. All zooplankton samples from both experiments were preserved in $4 \%$ formaldehyde (final concentration, wt/vol) and quantified by direct counts of several subsamples (McCauley 1984).

Chl a concentration. Chl a concentration was determined after filtration through Whatman GF/C filters. Filters with the retained seston were ground, extracted in $90 \%$ acetone, and measured spectrophotometrically after the method of Lorenzen (1967).

Phosphorus concentration. Total and dissolved reactive phosphorus were determined by the spectrophotometric method described in Kopáček \& Hejzlar (1993).

Statistical analysis. To tests for differences in microbial parameters as a function of time and treatment, data were first normalized by log-transformation. In the manipulation experiment, Expt 2, 1-way ANOVAs were applied to test for treatment-specific responses in selected microbial parameters at 48 and $96 \mathrm{~h}$. When these ANOVAs were significant, pairwise comparisons between individual treatments were made by means of Tukey's Honestly Significant Difference (HSD)-test (Stell \& Torrie 1980).

\section{RESULTS}

\section{Methodology}

Based on characteristic cell size, morphology, attachment to diatom surfaces (see 'Materials and methods'), and the manner in which prey FLB were arranged in food vacuoles, we could relatively easily identify typical sessile bacterivorous choanoflagellates of the genus Salpingoeca, which were present in large numbers on planktonic colonies of Asterionella formosa and Fragilaria crotonensis (Fig. 1). A typical example of FLB uptake data distribution (FLB Salpingoeca sp. cell $^{-1}$ at 10, 20 and $30 \mathrm{~min}$ ), and the linear fit of mean number of FLB cell ${ }^{-1}$ with time is shown in Fig. 2. The proportion of Salpingoeca sp. displaying no FLB uptake decreased steadily as a function of time, from $41 \%$ at $10 \mathrm{~min}$ to $13 \%$ at $30 \mathrm{~min}$. Under temperatures typical for both experiments $\left(\sim 20\right.$ to $\left.23^{\circ} \mathrm{C}\right)$; incubation times longer that $30 \mathrm{~min}$ resulted in only a negligible (if any) decrease in the proportion of the flagellate population displaying no FLB uptake. However, FLB ingested at the beginning of incubation were partially digested after $30 \mathrm{~min}$ (data not shown), making a precise estimate of food vacuole content difficult. Thus, an incubation time of 30 min was deemed optimal for routine measurements and for detecting the majority of feeding individuals of Salpingoeca sp., and also for determining food-vacuole content of the flagellate (cf. Figs. $1 \& 2$ ).

Fig. 3 shows 4 examples of data distribution of FLB cell $^{-1}$ after 30 min incubation, when $>150$ individuals were examined per sample. Generally, a uni-modal distribution occurred with only 8 to $16 \%$ of cells displaying no FLB ingestion (cf. Figs. $2 \mathrm{C} \& 3$ ), and with uptake rates ranging from 0 to $10 \mathrm{FLB}^{\mathrm{cell}}{ }^{-1}$ (cf. also Fig. 1C to F).

\section{Bacterivory of Salpingoeca sp. in Expt 1}

This experiment was conducted during the late clear water phase (12 to 16 June 2000), when a relatively high abundance of filter-feeding daphnids was recorded: Daphnia galeata (51 to 61 ind. $\mathrm{l}^{-1}$ ) and Diaphanosoma brachyurum (5 to 15 ind. $\mathrm{l}^{-1}$ ). (For details of the zooplankton composition in the dam area of the reservoir see Table 3 in Šimek et al. 2003). During Expt 1, there was a relatively stable chl a concentration, with $9.5 \mu \mathrm{g} \mathrm{l}^{-1}$ at the beginning and $10.7 \mu \mathrm{g} \mathrm{l}^{-1}$ at the end of the study. However, there was a gradual increase in the abundance of Asterionella formosa (from $\sim 140$ to 300 colonies $\mathrm{ml}^{-1}$, Fig. 4), with this species largely replacing cryptophytes that dominated at the beginning of the study (data not shown).

In all cases, $>85 \%$ of the Salpingoeca sp. cells were attached to Asterionalla formosa colonies, with the reminder attached to the much less abundant colonies of Fragilaria crotonensis (data not shown). Except for these 2 diatoms, we observed no other large and abundant algal species with attached choanoflagellates. Thus, practically the entire choanoflagellate population was attached to these 2 planktonic diatoms, and only rarely were they observed among free-swimming HNF. The average number $( \pm \mathrm{SD})$ of Salpingoeca sp. cells per A. formosa colony decreased from $2.5( \pm 4.5$, range 0 to 21) flagellate cells diatom colony ${ }^{-1}$ at $t_{0}$ to $0.9\left( \pm 1.7\right.$, range 0 to 7 ; data not shown) at $t_{96} \mathrm{~h}$. A decrease in size of the of $F$. crotonensis colonies (from 21 to 9 diatom cells per colony) toward the end of the study was accompanied by a drop in the number of Salpingoeca sp. cells: from 4.7 to 0.8 (range 0 to 35 ) choanoflagellates per colony. 

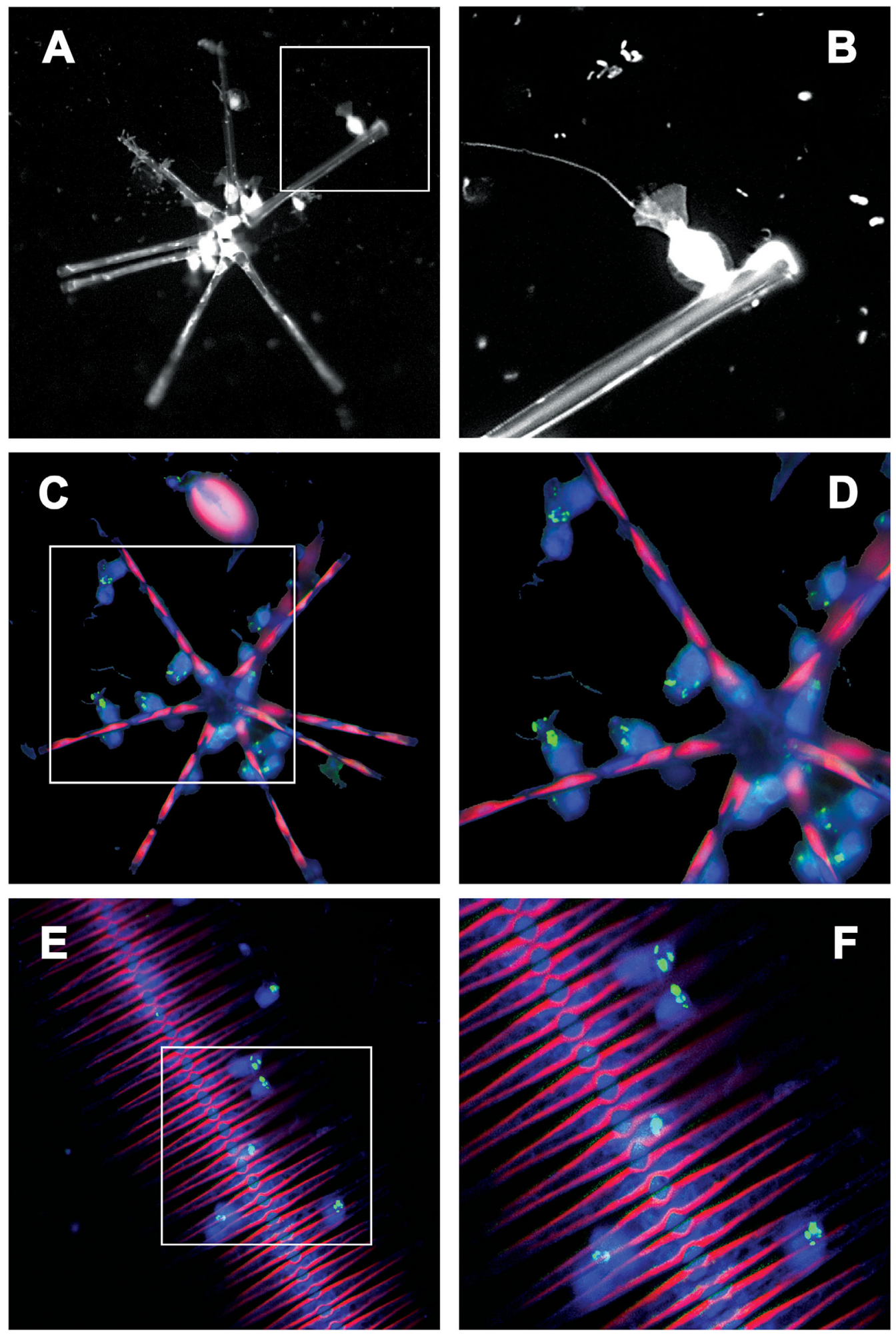

Fig. 1. Salpingoeca sp. attached to diatom colonies of (A-D) Asterionella formosa and (E,F) Fragilaria crotonensis. Areas outlined in white in (A), (C) and (E) are enlarged in (B), (D) and (F), respectively. (A) DAPI-stained image of A. formosa colony densely covered by Salpingoeca sp.; (B) single Salpingoeca sp. cell showing typical cell attachment, collar morphology, and single flagellum; (C) whole A. formosa colony with attached cells of Salpingoeca sp. ingesting fluorescently labeled bacteria, FLB; (D) detail from colony in (C); (E) large colony of F. crotonensis showing several cells of Salpingoeca sp. containing ingested FLB;

(F) detail of cells in (E) 

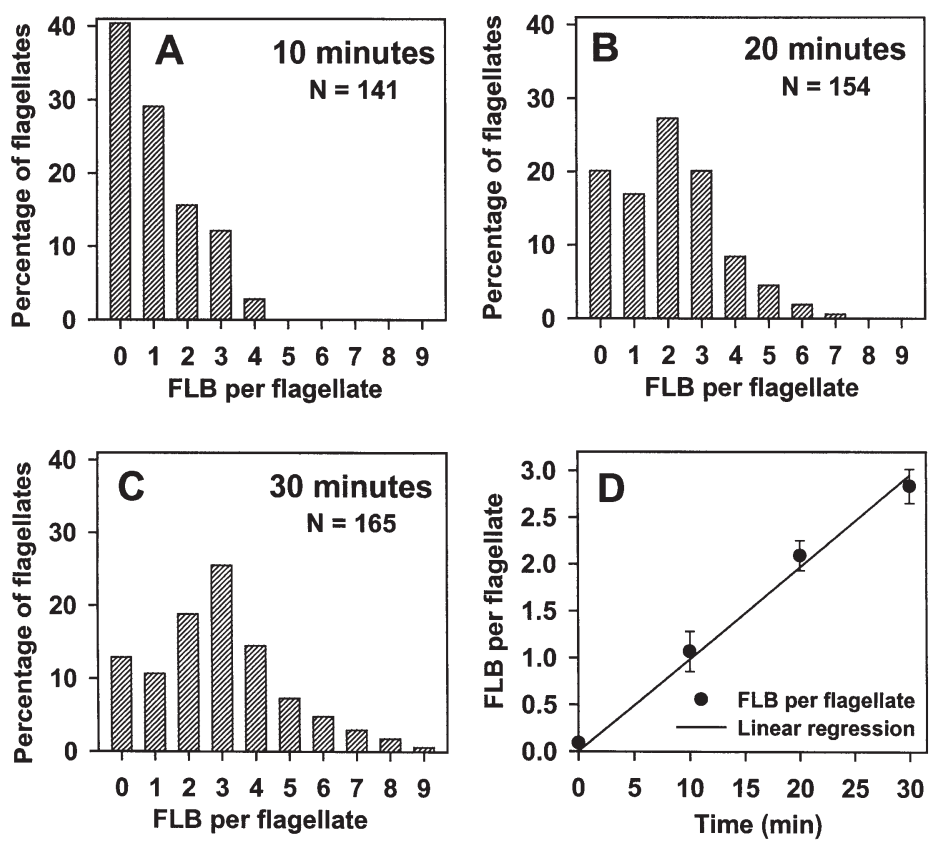

Fig. 2. Expt 1. Short-term FLB-uptake measurements (tracer = $14.6 \%, 14$ June 2000) showing typical data distribution of uptake rates of Salpingoeca sp. (FLB cell ${ }^{-1}$ ) at 10, 20, and 30 min (A-C); (D) fit of the data with linear regression model. N: number of choanoflagellate cells inspected at each time point; error bars in (D) $=$ SE of the mean. Tracer $=$ percentage of FLB added in relation to total number of bacteria in sample
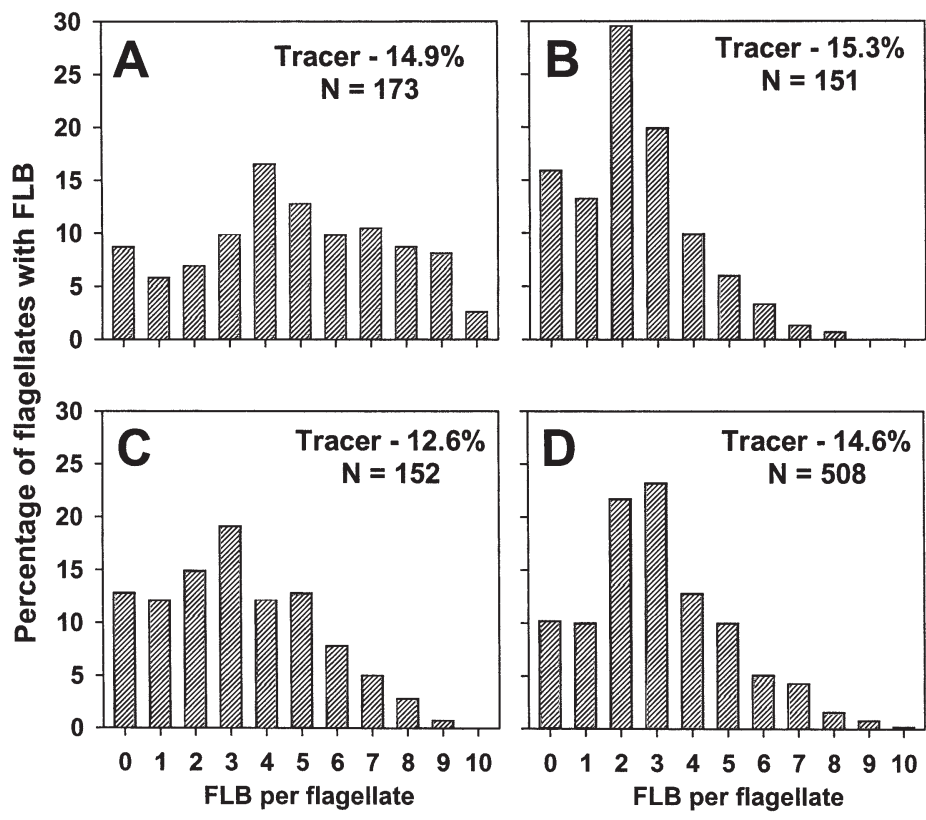

Fig. 3. Expt 2. Four examples of data distribution of uptake rates of Salpingoeca sp. (FLB cell ${ }^{-1}$ at $30 \mathrm{~min}$ ) (at least 150 individuals examined per sample). (A) reservoir (9 September 2002); (B-D) reservoir, control and + GLU treatments, respectively (11 September 2002). N: number of choanoflagellate cells inspected per sample
During the course of the study, bacterial numbers dropped from 3.7 to $1.6 \times 10^{6}$ cells ml $^{-1}$, while total HNF numbers showed an opposite trend, with a slight increase from 4.7 to $6.1 \times 10^{3}$ cells ml $^{-1}$ (Fig. 4). Only the densities of Salpingoeca sp. (generally 3 to $4 \times 10^{2}$ cells $\mathrm{ml}^{-1}$ ) showed no clear trend. Cell-specific bacterivory of Salpingoeca sp. (36 to 56 bacteria ind. ${ }^{-1} \mathrm{~h}^{-1}$, mean $\pm \mathrm{SD}=42 \pm 9$ ) was significantly higher than that estimated on the basis of total HNF (11 to 31 bacteria ind. ${ }^{-1} \mathrm{~h}^{-1}$, mean \pm SD, $22 \pm 8$, Fig. 4). The total bacterivory of Salpingoeca sp. populations alone contributed 12 to $19 \%$ to the daily removal rate of bacterial standing stock, with the highest mortality rates found at the end of the study together with a marked decrease in bacterial abundance (cf. Table 1, Fig. 4). Over-
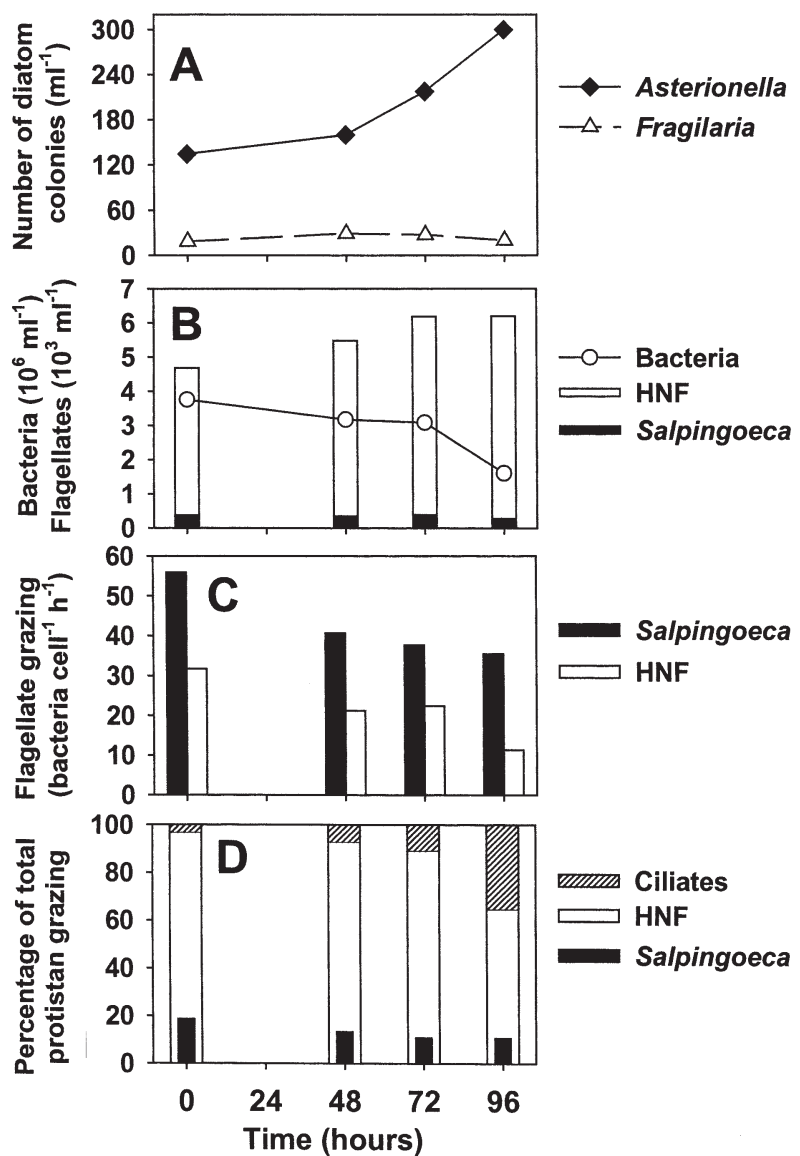

Fig. 4. Expt 1. (A) Changes over time in abundance of diatom colonies of Asterionella formosa and Fragilaria crotonensis; (B) abundance of bacteria, total heterotrophic nanoflagellates (HNF) and Salpingoeca sp.; (C) cell-specific bacterivory of Salpingoeca sp. compared to that calculated on the basis of total HNF; (D) relative contributions of total HNF, Salpingoeca sp., and ciliates to total protozoan bacterivory. Data are means of 2 replicate treatments 
Table 1. Daily bacterial mortality $\left(\% \mathrm{~d}^{-1}\right)$ due to Salpingoeca sp. grazing expressed as \% bacterial standing stock in Expts 1 (12 to 16 June 2000) and 2 (9 to 13 September 2002). Data are means of 2 duplicate treatments. + P: phosphorus addition; + Glu: glucose addition $;+\mathrm{P}+$ Glu: phosphorus and glucose addition

\begin{tabular}{|c|c|c|c|c|c|c|}
\hline \multirow{2}{*}{ Time (h) } & \multirow{2}{*}{$\begin{array}{l}\text { Expt } 1- \\
\text { Unfiltered water }\end{array}$} & & & \multirow{2}{*}{$\begin{array}{l}\text { Expt } 2 \\
+\mathrm{P}\end{array}$} & \multirow[b]{2}{*}{ + GLU } & \multirow[b]{2}{*}{$+\mathrm{P}+\mathrm{GLU}$} \\
\hline & & Reservoir & Control & & & \\
\hline 0 & 15 & 6 & 6 & 6 & 6 & 6 \\
\hline 48 & 12 & 14 & 29 & 32 & 25 & 11 \\
\hline 96 & 19 & 30 & 40 & 49 & 41 & 48 \\
\hline
\end{tabular}

all, bacterivory of HNF and Salpingoeca sp. accounted for 65 to $97 \%$ and 11 to $19 \%$ of the total protistan bacterivory, respectively, with the highest values at the beginning of the study. However, at the end of the experiment the role of ciliate bacterivory became increasingly important (Fig. 4) with ciliate concentrations increasing from 12 to 44 cells ml$^{-1}$ (for details see Šimek et al. 2003).

\section{Bacterivory of Salpingoeca sp. in Expt 2}

Expt 2 was conducted from 9 to 13 September 2002, with an initial moderate abundance of filter-feeding daphnids: Daphnia galeata (23 ind. $\mathrm{1}^{-1}$ ); Diaphanosoma brachyurum and Ceriodaphnia quadrangula (pooled = 8 ind. $\mathrm{l}^{-1}$ ); and rotifers (360 ind. $\mathrm{l}^{-1}$, data not shown) with $>80 \%$ dominated by Polyarthra sp.

By the end of the experiment, the nutrient manipulation had induced significant changes in chl a concentrations (Table 2) between treatments (1-way ANOVA, $F=1876, \mathrm{p}<0.001)$. Pairwise comparisons of differences (Tukey's HSD-test) between the individual treatments at $t_{96}$ revealed that these were not significant between reservoir, control and + GLU treatments, while in $+\mathrm{P}$ and $+\mathrm{P}+$ GLU treatments marked increases in chl a concentrations (Table 2) yielded significant differences compared to all other treatments $(p<0.001)$. Interestingly, the most marked chl a increase was in the treatment with $\mathrm{P}$ addition only, while this increase was significantly different (Tukey's HSD-test, $\mathrm{p}<0.001$ ) and less pronounced in the P + GLU treatment with the same amount of orthophosphate addition. Basically the same pattern was found for marked differences in the final abundance of Fragilaria crotonensis at $t_{96}$, with the highest abundance in the $+\mathrm{P}$ treatment followed by the + P + GLU treatment. The other 3 treatments showed very similar but much smaller increases in diatom abundance (Fig. 5).

Across all treatments, $>90 \%$ of total Salpingoeca sp. cells were always attached to Fragilaria crotonensis colonies, with the reminder attached to colonies of Asterionella formosa (data not shown). The average number $( \pm \mathrm{SD})$ of Salpingoeca sp. cells per F. crotonensis colony was $2.1( \pm 2.5$, range $=0$ to 29$)$ flagellates per diatom colony, with no clear pattern in any of the experimental treatments. However, in all treatments, changes in Salpingoeca sp. abundance (Fig. 5) were very closely linked to changes in the number of diatom colonies of $F$. crotonensis $\left(\mathrm{r}^{2}=0.94, \mathrm{n}=15, \mathrm{p}<0.001\right)$, which thus clearly represents the most important substratum for choanoflagellate attachment. Correspondingly, the highest abundance of Salpingoeca sp. (2.399 and $1.700 \times 10^{3}$ ind. $\mathrm{ml}^{-1}$ ) was observed in $+\mathrm{P}$ and $+\mathrm{P}$ + GLU treatments, respectively (Fig. 5), along with the most marked increases in F. crotonensis colony abundance at $t_{96}$.

In contrast to chl a concentration (Table 2) or diatom abundance (Fig. 5), bacterial abundance decreased in a very similar pattern in all treatments, with no significant treatment-specific response to experimental manipulation (1-way ANOVA, $F=1.84, \mathrm{p}>0.25)$. The HNF grazer populations, however, showed very different responses to experimental manipulation. While HNF abundance increased only slightly in the reservoir, it displayed a distinct pattern in all barrel treatments, resulting in highly significant differences among treatments at $t_{96} \mathrm{~h}$ (1-way ANOVA, $F=26.2$, p < 0.0015). Thus, containment of the non-manipulated control in a barrel induced a different HNF abundance than in samples taken directly from the reservoir. Treatments with glucose addition (+ GLU and + P + GLU) resulted in a sharp increase in HNF abundance at $t_{48}$, followed however, by a dramatic decrease at $t_{96}$,

Table 2. Changes in chlorophyll a concentrations $\left(\mu \mathrm{gl}^{-1}\right)$ in different treatments in Expt 2. + P: phosphorus addition; + Glu: glucose addition $;+$ P + Glu: phosphorus and glucose addition. Data are means of 2 duplicate treatments

\begin{tabular}{|lrrrrr|}
\hline Time (h) & Reservoir & Control & $+\mathrm{P}$ & + GLU & + P + GLU \\
\hline 0 & 9.9 & 9.9 & 9.9 & 9.9 & 9.9 \\
48 & 12.5 & 12.0 & 27.0 & 12.3 & 27.9 \\
96 & 11.9 & 11.7 & 74.0 & 12.1 & 48.6 \\
\hline
\end{tabular}




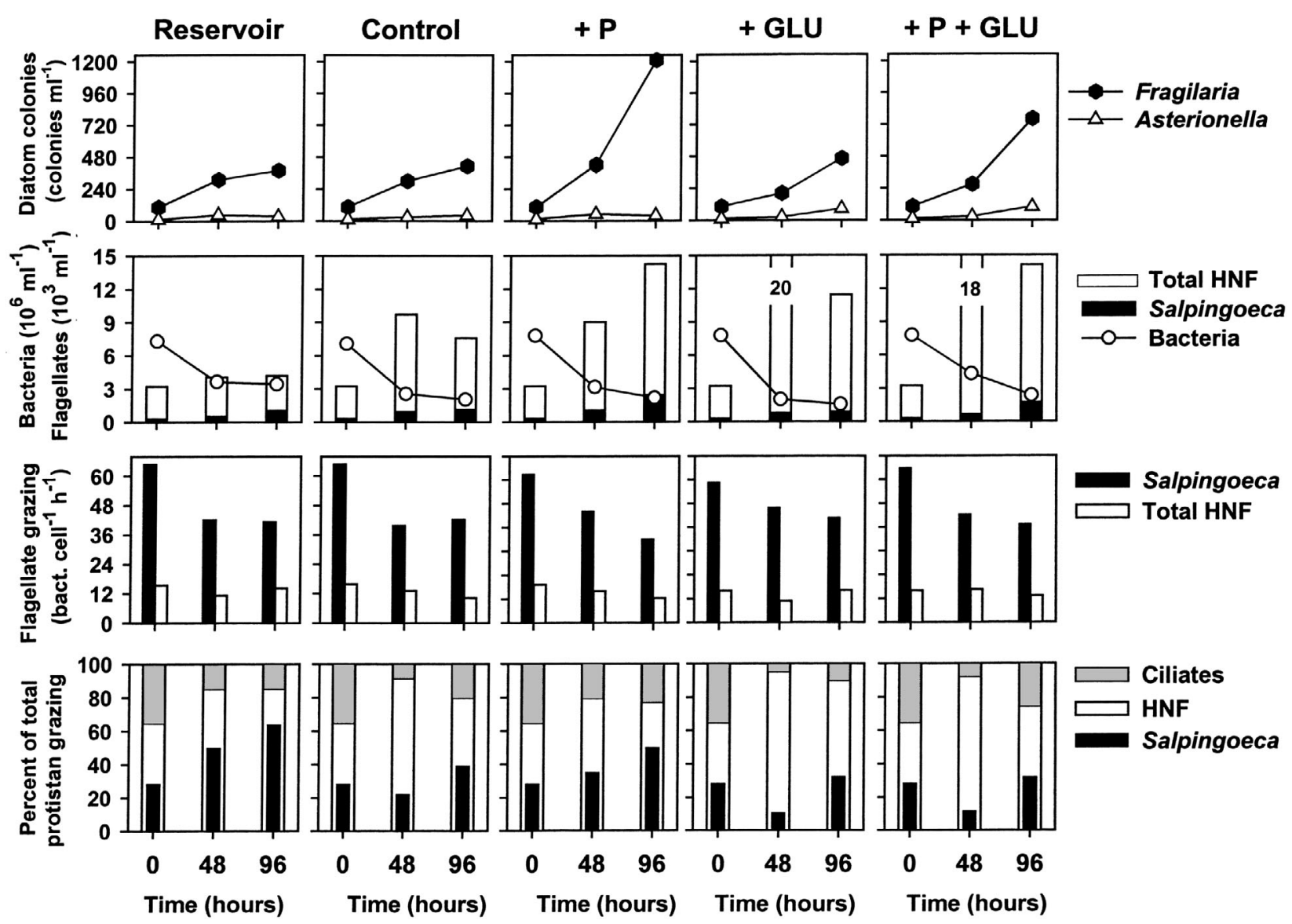

Fig. 5. Expt 2. Changes over time in abundance of colonies of Asterionella formosa and Fragilaria crotonensis (top row of graphs); abundance of bacteria, total heterotrophic nanoflagellates (HNF) and of Salpingoeca sp. (2nd row); cell-specific bacterivory of Salpingoeca sp. compared to that calculated on the basis of total HNF (3rd row); relative contributions of total HNF, Salpingoeca sp., and ciliates into total protozoan bacterivory (bottom row). Data are means of 2 replicate treatments. + P: phosphorus added; + Glu: glucose added + P + Glu: phosphorus and glucose added

while in the $+\mathrm{P}$ treatment a steady increase in $\mathrm{NHF}$ abundance was observed over time (Fig. 5).

The cell-specific bacterivory of Salpingoeca sp. shown in Fig. 5 (35 to 65 bacteria ind $\mathrm{d}^{-1} \mathrm{~h}^{-1}$; mean $\pm \mathrm{SD}$ $=50 \pm 11$ ) was significantly higher than that of the total

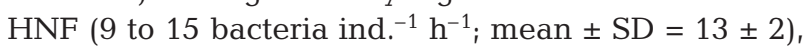
and was tightly correlated with bacterial abundance ( $\mathrm{n}=15, \mathrm{p}<0.001, \mathrm{r}^{2}=0.835$ and 0.362 for Salpingoeca and HNF, respectively). Across all treatments, bacterivory of total HNF, Salpingoeca sp. alone, and total ciliates accounted for 65 to $95 \%, 11$ to $64 \%$, and 5 to $35 \%$ of total protistan bacterivory, respectively (see Fig. 5). During the course of the study, a consistent increase in and the most pronounced contribution of Salpingoeca sp. to total bacterivory was detected in the reservoir and $+\mathrm{P}$ treatments, while both treatments with glucose addition (GLU and + P + GLU) were associated with increases in free-swimming HNF (Fig. 5). The total bacterivory of Salpingoeca sp. populations alone contributed 6 to $49 \%$ (mean $\pm \mathrm{SD}=24 \pm 16 \%$ ) to the daily removal rate of bacterial standing stock, with the highest mortality rates occurring at the end of the study along with a grazing-induced, marked decrease in bacterial abundance (cf. Table 1 \& Fig. 5).

\section{DISCUSSION}

Variability in grazing rate estimates of choanoflagellates

Using the FLB technique, investigations of HNF bacterivory in aquatic systems have frequently revealed a large and variable proportion of individuals displying no FLB ingestion among communities of HNF species (e.g. Bratvold et al. 2000, Cleven \& Weisse 2001); this is also related to their very different ability to ingest bacterial particles. It is not therefore surprising that in 
some cases the distribution of uptake data for mixed natural assemblages of HNF can display a very large scatter, since it reflects not only intra-, but also interspecific variation in bacterivory, as well as the fact that non-bacterivorous taxa are included in estimates of the bulk rate of community bacterivory.

The aim of this study was not to assess the pros and cons of the FLB method, which has been repeatably discussed elsewhere (McManus \& Okubo 1991, Sherr \& Sherr 1993, Vaqué et al. 1994, Šimek et al. 2000), but to apply the technique to studying protistan speciesspecific bacterivory, and examine the ecological role and natural variability in grazing rates of a single choanoflagellate taxon in plankton samples.

We were able to unequivocally identify ecologically important bacterivorous choanoflagellates of the genus Salpingoeca inhabiting diatom colonies (Fig. 1). In the reservoir plankton, cells of Salpingoeca sp. ingested only heterotrophic bacteria or autotrophic picoplankton, and microscopic analysis revealed that these natural food items and the tracer FLB ingested were never $>3 \mu \mathrm{m}$. Moreover, statistical analysis supported the view that bacteria are the dominant prey of the choanoflagellate since $>83 \%$ of the variability in taxon-specific bacterivory of Salpingoeca sp. was explained by changes in bacterial abundance, while only $36 \%$ of this variability was explained when data for total mixed HNF communities were used. Salpingoeca sp. thus appears to be an easily identifiable, suitable representative of true pelagic bacterivores, enabling detailed examination of the natural variability in their uptake rates under in situ conditions.

Generally, the data on the uptake of FLB produced from the reservoir bacterioplankton (mean cell volume $\sim 0.1 \mu^{3}$ ) fitted well to a linear model for the first 30 min (Fig. 2D), with the tracers occupying a relatively small space in the choanoflagellate food vacuoles (Fig. 1C to F). The observed 30 min linear increase in food particles per cell supports literature reports of typical digestion times of auto- and heterotrophic picoplankton by HNF and ciliates (ranging

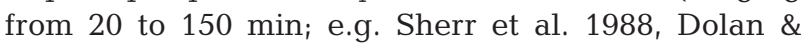
Šimek 1999 and references therein). On the other hand, our data do not support the conclusions of Boenigk et al. (2001) that prey surrogates such as FLB can be egested after a food-vacuole passagetime of only 2 to $3 \mathrm{~min}$. However, the latter study was entirely based on laboratory-grown flagellate and bacterial cultures with high predator and food concentrations, and an untypical size of bacterial prey (see, e.g., a large, highly motile single bacterial strain of non-aquatic origin in Boenigk et al. 2001) that greatly deviated from in situ conditions; thus, the applicability of their conclusions to the natural plankton environments is questionable.
We analyzed 5 sets of uptake data, whereby $>150$ clearly identifiable individuals of Salpingoeca sp. were examined per sample at 30 min under conditions of comparable bacterial abundance, tracer FLB addition (cf. Figs. $2 \& 3$ ) and temperature. Figs. $2 \mathrm{C} \& 3$ show that the number of FLB ingested ranged from 0 to 10 FLB cell $^{-1}$, consistently yielding an almost symmetrical distribution of prey data except for some asymmetry at the left end of the distribution due to 8 to $16 \%$ of Salpingoeca sp. individuals that ingested no FLB. In general, our data distribution resemble that obtained for ingestion of FLB by natural populations of the omnivorous Halteria sp. by Šimek et al. (2000) and they differed markedly from that for taxon-specific uptake rates presented by Cleven \& Weisse (2001), who observed significantly larger proportions of cells with no ingested FLB at 30 min incubations. Differences in protist physiology, nutritional status (e.g. Jürgens \& DeMott 1995, Christaki et al. 1998), periods of cell division or/and mouth formation can lead to such temporary non-feeding (Bratvold et al. 2000). Additionally, even small methodical modifications such as pre-filtration of FLB onto $1 \mu \mathrm{m}$ pore-size filters (Cleven \& Weisse 2001) can result in some deviation from the prey size structure in natural bacterioplankton.

Data documenting intraspecific variability in grazing rates of natural populations of bacterivorous flagellates are practically non-existent (see review by Weisse 2002). Based upon the tracer technique and our data distributions, we made tentative estimates of individual uptake rates and taxon-specific bacterivory (in parentheses) of Salpingoeca sp. ranging from 0 to 123 (41), 0 to 134 (66), 0 to 105 (43), 0 to 143 (38), and 0 to 137 (42) bacteria cell ${ }^{-1} \mathrm{~h}^{-1}$ (see Figs. $2 \mathrm{C} \& 3 \mathrm{~A}$ to $\mathrm{D}$, respectively). We are aware that, due to inherent constraints, the tracer technique does not reflect the total variability in feeding rates. However, taking into account the fact that $\sim 90 \%$ of cells of Salpingoeca sp. took up FLB within $30 \mathrm{~min}$, our data give certain approximations and valuable insight into possible variability in individual feeding rates.

There is some debate concerning the suitability of the FLB method for in situ measurements, a debate fueled largely by reports of variable results obtained using cultured protists feeding on bacterial prey cultures (e.g. Boenigk et al. 2001). The debate poses an ecologically relevant question: should one expect larger intraspecific variability in cultured protists or in natural populations of the same protistan species? While direct comparison for a single protistan species is probably impossible with the methods presently available, it is generally assumed (see e.g. Weisse 2002) that individual intraspecific variability in protist feeding is even larger in situ than under standardized laboratory conditions. While intuitively this argument 
sounds reasonable, one must bear in mind that all laboratory cultures are artificial systems with usually excessive food availability but an almost complete absence of natural selection and top-down pressure on the target protistan population. Such a combination of factors can possibly support groups of even slowergrowing and less-competitive individuals that are repeatedly re-inoculated into these favorable culture conditions, resulting in several physiologically different cohorts of protistan individuals. On the other hand, natural protist populations are exposed to permanent selection and thus one would expect that most of the slower growing and less competitive individuals would sooner or later be removed by predation or bottom-up constraints inherent in the environment. Summing up, there is no clear evidence that natural populations in the same locality at the same time display a large scatter of feeding rates. Our data, based on short-term measurements of feeding rates of bacterivorous ciliates (Šimek et al. 2000) and choanoflagellates (this study) do not support such a hypothesis.

\section{Importance of choanoflagellate bacterivory}

Although choanoflagellates are generally considered potentially important bacterivores, with a few exceptions (Carrias et al. 1996, Šimek et al. 1997, Cleven \& Weisse 2001), we lack data on bacterivory by single choanoflagellate taxa in the plankton. For Lake Pavin (France) Carrias et al. (1996) reported that diatom-attached HNF (mostly choanoflagellates and bicoecids) had a high clearance rate and might account in some depths for $60 \%$ of the total protistan bacterivory. Also, data from other lakes indicate that particle-bound choanoflagellates (unfortunately mostly non-identified taxa) are highly efficient picoplankton grazers, with taxon-specific bacterivory ranging from $\sim 30$ to 73 bacteria cell ${ }^{-1} \mathrm{~h}^{-1}$ (Sanders et al. 1989, Vaqué \& Pace 1992, Carrias et al. 1996, Hwang \& Heath 1997, Šimek et al. 1997). This supports the idea that, in terms of feeding rates, attachment to surfaces is the most favorable strategy for suspension-feeding protozoans (Fenchel 1986, Christensen-Dalsgaard \& Fenchel 2003), giving them the competitive advantage of a high bacterial uptake rate that allows a high growth rate.

While on a per capita basis choanoflagellates undoubtedly belong to the most efficient pelagic bacterivores among HNF, they are usually not the most abundant or quantitatively the most important bacterivores in plankton; this role is usually attributed to small Spumella-like chrysomonads (Sanders et al. 1989, Bennet et al. 1990, Mathes \& Arndt 1994, Šimek et al. 1997). However, under specific conditions such as a sufficient abundance of suitable host algae (Vaqué \&
Pace 1992) the contribution of choanoflagellates to overall bacterivory can become important (cf. Carrias et al. 1996, and Figs. 4 \& 5 of this study).

\section{Factors affecting dynamics and overall importance of bacterivory in Salpingoeca sp.}

Our study has documented that there are clearly identifiable flagellate taxa that can temporarily play a key role as pelagic bacterivores. The genus Salpingoeca may be an example of an ecologically important and neglected taxon that significantly contributes to overall bacterial mortality. To our knowledge this study is the first one to report grazing rates of a specific choanoflagellate taxon, Salpingoeca sp. (probably $S$. amphoridium), on natural bacterioplankton (Figs. 4 \& 5). We have shown that this taxon has significantly higher taxon-specific uptake rates of bacteria than other HNFs in the community (Figs. 4 \& 5), which was numerically dominated by small chrysomonads.

To estimate the potential growth rate of Salpingoeca sp. in situ, its cell-specific volume $\left(44 \mu^{3}\right)$ and the cell volumes of its ingested bacterial prey were transformed into carbon units using the conversion factors

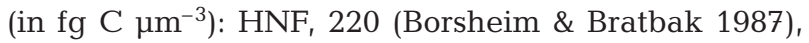
bacteria, 196 and 226 (according to Norland 1993, these would correspond to a mean cell volume for the reservoir bacteria of 0.082 and $0.128 \mu^{3}$ in Expts 1 and 2, respectively). Assuming a gross growth efficiency of $40 \%$ for bacterivorous HNF (Fenchel 1982) and using our mean ingestion rate values of 42 and 50 bacteria cell ${ }^{-1} \mathrm{~h}^{-1}$ in Expts 1 and 2, respectively, the doubling times of the choanoflagellate would be 23 and $26 \mathrm{~h}$. This agrees with previous estimates of choanoflagellate growth rate in situ (Šimek et al. 1997), supporting our view that these are highly specialized bacterivores with the ability to grow rapidly on a bacterioplankton diet alone. However, some caution is needed since we determined the biovolume of Salpingoeca sp. from formaldehyde-fixed samples and, in the case of Salpingoeca sp., this can lead to more than $50 \%$ of cell shrinkage compared to live volume (Sonntag et al. 2000). If this effect is taken into account, then the estimated doubling times would be about twice as long. On the other hand, pelagic flagellates occasionally ingest not only heterotrophic but also autotrophic picoplankton in the reservoir, and this would represent an important additional carbon source (Synechococcus spp., see Šimek et al. 1997), whose inclusion in the above calculation would result in shorter doubling-times.

A common feature of our experiments was that they were conducted during periods of high abundance of diatom colonies along with an enhanced (Expt 1) or 
moderate abundance (Expt 2) of filter-feeding daphnids or rotifers, which are considered highly efficient grazers of free-swimming HNF (Pace et al. 1990, Šimek et al. 1990, Arndt 1993, Jürgens 1994). Thus, the increased role of Salpingoeca sp. bacterivory during such periods may be related to the increased probability of attached choanoflagellates escaping cladoceran or rotifer grazing pressure by using diatom colonies as a refuge from grazers. While the colonies of Asterionella formosa might be partially vulnerable to grazing by large cladocerans (Infante 1973), the very large blocks of Fragilaria spp. are likely not (Lampert 1977, Osgood 1982). Individual Salpingoeca sp. cells were sometimes observed among free-swimming HNF even during periods when diatoms were absent or present in very low abundance. However, their proportions within the HNF community as a whole were very low, indicating that free-swimming individuals are vulnerable to zooplankton predation.

It is worthy of note that, in Expt 1, in which Asterionella formosa was the main substratum for choanoflagellate attachment, overall bacterivory of Salpingoeca sp. did not exceed $20 \%$ of total protistan bacterivory whereas in Expt 2, in which Fragilaria crotonensis was the main substratum, overall bacterivory of Salpingoeca sp. accounted for 11 to $64 \%$ of total protistan bacterivory (Fig. 5), and frequently $>10$ individual Salpingoeca sp. cells were observed on a single diatom colony. Also, the fact that $>80 \%$ of the rotifer community was dominated by Polyarthra sp. (a rotifer capable of preying on free-swimming single flagellate cells such as HNF; Pouriot 1987, Dolan \& Gallegos 1991) could have significantly contributed to the overall increase in bacterivory of the diatom-bound choanoflagellates in Expt 2.

With regard to the exceptional role of diatoms in the choanoflagellate dynamics, we found that the abundance of Salpingoeca sp. was very tightly linked to and significantly correlated with the abundance of colonial planktonic diatoms, while no marked colonization of other algae was observed during the present experiments or on a seasonal basis (Šimek unpubl. data). In the oligotrophic alpine lake Traunsee (Austria), members of the Salpingoeca genus are even found exclusively attached to Asterionella formosa colonies (B. Sonntag pers. comm.).

We tried to determine experimentally the role of algal host abundance and bacterial prey in the dynamics of Salpingoeca sp. and other HNF (Fig. 5). Increased P availability in + P and + P + GLU treatments significantly increased the growth of Fragilaria crotonensis, resulting in subsequent increases in the abundance of Salpingoeca sp. However, when expressed as the relative contribution of Salpingoeca sp. to total protistan grazing (Fig. 5), the reservoir samples and the $+\mathrm{P}$ treatment generally had the highest values, with a steadily increasing role of choanoflagellate bacterivory. In contrast, while the reservoir and control treatments showed an almost identically slow increase in the densities of diatoms and Salpingoeca sp., the relative contribution of choanoflagellate bacterivory was much less important in the control than in the reservoir treatment. Obviously, zooplankton grazing on small free-swimming flagellates was less efficient in the barrels than in the open reservoir water.

The treatments amended with glucose (+ GLU and + P + GLU) generally presented a more complicated scenario. While (surprisingly) no significant change in bacterial numbers could be directly detected as a response to such amendment, commonly small freeswimming Spumella-like HNF clearly profited from this pulse of organic carbon. These cells showed a marked peak in abundance at $t_{48} \mathrm{~h}$ that did not occur in other treatments (Fig. 5). Apparently, the accelerated growth of heavily grazed bacteria in these organically amended treatments facilitated this outbreak of fastgrowing, free-swimming HNF. Correspondingly, in the second half of Expt 2 the relative contribution of Salpingoeca sp. (although also growing fast in $+\mathrm{P}+$ GLU treatment) to total protistan bacterivory was smaller in the + GLU and + P + GLU treatments than in the other treatments. This also indicates a large growth potential of small (2 to $4 \mu \mathrm{m}$ diameter), free-swimming chrysomonads provided with an increased food supply (cf. Arndt et al. 2000, Šimek et al. 2003).

The combined effect of $\mathrm{P}$ and glucose additions supported the microbial pathway from organic carbon via bacteria to HNF, similar to the + GLU treatment. However, compared to the treatment with $\mathrm{P}$ addition alone, more $\mathrm{P}$ was consumed by fast-growing microorganisms in the combined $+\mathrm{P}+$ GLU treatment, resulting in a more severe competition for this limiting nutrient. This is consistent with the slower growth of algae in $+\mathrm{P}+\mathrm{GLU}$ than in the $+\mathrm{P}$ treatment (cf. Table 2, Fig. 5).

At different trophic levels of freshwater plankton food webs, there are apparently key species that significantly affect carbon flow and microbial food-web structure, such as filter-feeding cladocerans (see Pace et al. 1990, Jürgens 1994), small algivorous prostomatids that regulate the dynamics of nanophytoplankton (e.g. Müller 1989, Sommaruga \& Psenner 1993), and small omnivorous oligotrichs that have marked grazing impacts on the bacterioplankton (Šimek et al. 2000) and HNF (Jürgens et al. 1996). In this study, we have detected an important but largely neglected diatom-attached pelagic choanoflagellate, Salpingoeca sp., which displays very high rates of bacterivory. Under certain circumstances, this choanoflagellate can form large populations, and thus 
temporarily comprise the most important pelagic bacterivore. These circumstances consist primarily of a sufficiently high abundance of colonial diatoms that offer a suitable substratum for Salpingoeca sp. attachment, a competitive advantage of an enhanced growth rate, and a refuge from potential grazers. Additionally, increased numbers of filter-feeding cladocerans contribute specifically to the relative importance of the choanoflagellates as bacterivores by eliminating a large proportion of rapidly growing, free-swimming small HNF that compete directly with the choanoflagellates for bacterial food.

Acknowledgements. This study was largely supported by the Grant Agency of the Czech Republic under research grant 206/02/0003 awarded to K. Šimek, and partly by the project MSM 123100004 ('Structure and functioning of the system water-soil-plant'). We wish to thank J. Dolan, T. Posch and 4 anonymous reviewers for English corrections and the valuable comments on the earlier versions of the paper, B. S. C. Leadbeater and $\mathrm{H}$. Arndt for assistance with choanoflagellate identification, M. Mašín and J. Nedoma for assistance with experimental sampling in the reservoir, J. Hejzlar for chemical analysis, and S. Smrčková and R. Malá for excellent technical assistance.

\section{LITERATURE CITED}

Arndt H (1993) Rotifers as predators on components of the microbial web (bacteria, heterotrophic flagellates, ciliates) - a review. Hydrobiologia 255/256:231-246

Arndt H, Dietrich D, Auere B, Cleven EJ, Gräfenhan T, Weitere M, Mylnikov AP (2002) Functional diversity of heteroterophic flagellates in aquatic ecosystems. In: Leadbeater BSC, Green JC (eds) The flagellates. Taylor \& Francis, London, p 240-268

Bennett SJ, Sanders RW, Porter KG (1990) Heterotrophic, autotrophic, and mixotrophic nanoflagellates: Seasonal abundance and bacterivory in a eutrophic lake. Limnol Oceanogr 35:1821-1832

Berninger UG, Finlay BJ, Kuuppo-Leinikki P (1991) Protozoan control of bacterial abundances in freshwaters. Limnol Oceanogr 36:139-147

Boenigk J, Arndt H, Cleven EJ (2001) The problematic nature of fluorescently labeled bacteria (FLB) in Spumella feeding experiments - an explanation by using video microscopy. Arch Hydrobiol 152:329-338

Borsheim KY, Bratbak G (1987) Cell volume to carbon conversion factors for a bacterivorous Monas sp. enriched from seawater. Mar Ecol Prog Ser 36:171-175

Bratvold D, Srienc F, Taub SR (2000) Analysis of the distribution of ingested bacteria in nanoflagellates and estimation of grazing rates by flow cytometry. Aquat Microb Ecol 21: $1-12$

Caron DA, Dennett MR (1986) Effects of temperature on growth, respiration, and nutrient regeneration by an omnivorous microflagellate. Appl Environ Microbiol 52: 1340-1347

Carrias JF, Amblard C, Bourdier G (1996) Protistan bacterivory in an oligomesotrophic lake: importance of attached ciliates and flagellates. Microb Ecol 31:249-268

Cho BC, Na SC, Choi DH (2000) Active ingestion of fluorescently labeled bacteria by mesoplegic heterotrophic nanoflagellates in the East Sea, Korea. Mar Ecol Prog Ser 206:23-32

Christaki U, Dolan JR, Pelegri S, Rassoulzadegan F (1998) Consumption of picoplankton-size particles by marine ciliates - effects of physiological-state of the ciliate and particle quality. Limnol Oceanogr 43:458-464

Christensen KK, Fenchel T (2003) Increased filtration efficiency of attached compared to free-swimming flagellates. Aquat Microb Ecol 33:77-86

Cleven EJ, Weisse T (2001) Seasonal succession and taxonspecific bacterial grazing rates of heterotrophic nanoflagellates in Lake Constance. Aquat Microb Ecol 23: $147-161$

Dolan JR, Gallegos CL (1991) Trophic coupling of rotifers, microflagellates, and bacteria during fall months in Rhode River Estuary. Mar Ecol Prog Ser 77:147-156

Dolan RJ, Šimek K (1999) Diel periodicity in Synechococcus and grazing by heterotrophic nanoflagellates: analysis of food vacuole contents. Limnol Oceanogr 44:1565-1570

Fenchel T (1982) Ecology of heterotrophic nanoflagellates. IV. Quantitative occurrence and importance as bacterial consumers. Mar Ecol Prog Ser 9:35-42

Fenchel T (1986) Protozoan filter feeding. Prog Protistol 1: 65-113

Gasol JM, Simons AM, Kalff J (1995) Patterns in the top-down versus bottom-up regulation of heterotrophic nanoflagellates in temperate lakes. J Plankton Res 17:1879-1903

Hwang SJ, Heath RT (1997) Bacterial productivity and protistan bacterivory in coastal and offshore communities of lake Erie. Can J Fish Aquat Sci 54:788-799

Infante A (1973) Untersuchungen über die Ausnutzbarkeit verschiedener Algen durch das Zooplankton. Arch Hydrobiol (Suppl) 48:340-405

Jürgens K (1994) Impact of Daphnia on planktonic microbial food webs. A review. Mar Microb Food Webs 8:295-324

Jürgens K, DeMott WR (1995) Behavioral flexibility in prey selection by bacterivorous nanoflagellates. Limnol Oceanogr 40:1503-1507

Jürgens K, Wickham SA, Rothhaupt KO, Santer B (1996) Feeding rates of macro- and microzooplankton on heterotrophic nanoflagellates. Limnol Oceanogr 41:1833-1839

Kopáček J, Hejzlar J (1993) Semi-micro determination of total phosphorus in fresh waters with perchloric acid digestion. Int J Environ Anal Chem 53:173-183

Lampert W (1977) Studies on the carbon balance of Daphnia pulex DeGeer as related to environmental conditions. II. The dependence of carbon assimilation on animal size, temperature, food concentration and diet species. Arch Hydrobiol Suppl 48:310-335

Lim EL, Dennett MR, Caron DA (1999) The ecology of Paraphysomonas imperforata based on studies employing oligonucleotide probe identification in coastal water samples and enrichment cultures. Limnol Oceanogr 44:37-51

Lorensen CJ (1967) Determination of chlorophyll and phaeopigments. Spectrophotometric equations. Limnol Oceanogr 12:343-346

Mathes J, Arndt H (1994) Biomass and composition of protozooplankton in relation to lake trophy in north German lakes. Mar Microb Food Webs 8:357-375

McCauley E (1984) The estimation of the abundance and biomass of zooplankton in samples. In: Downing JA, Rigler FH (eds) A manual on methods for the assessment of secondary productivity in fresh waters. Blackwell, Oxford, p 228-266

McManus GB, Okubo A (1991) On the use of surrogate food particles to measure protistan ingestion. Limnol Oceanogr 36:613-617 
Müller H (1989) The relative importance of different ciliate taxa in the pelagic food web of Lake Constance. Microb Ecol 18:261-274

Norland S (1993) The relationship between biomass and volume of bacteria. In: Kemp PF, Sherr BF, Sherr EB, Cole JJ (eds) Handbook of methods in aquatic microbial ecology. Lewis Publishers, Boca Raton, FL, p 303-308

Osgood RA (1982) Differential filtration efficiencies of Daphnia pulex. Can J Zool 60:2129-2133

Pace ML, McManus GB, Findlay SEG (1990) Planktonic community structure determines the fate of bacterial production in a temperate lake. Limnol Oceanogr 35:795-808

Posch T, Pernthaler J, Alfreider A, Psenner R (1997) Cellspecific respiratory activity of aquatic bacteria studied with the tetrazolium reduction method, cyto-clear slides, and image analysis. Appl Environ Microbiol 63:867-873

Pourriot R (1977) Food and feeding habits of Rotifera. Arch Hydrobiol Beih Ergebn Limnol 8:243-260

Sanders RW (1991) Trophic strategies among heterotrophic flagellates. In: Patterson DJ, Larsen J (eds) The biology of free-living heterotrophic flagellates. Clarendon Press, Oxford, p 21-38

Sanders RW, Porter KG, Bennet SJ, DeBiase AE (1989) Seasonal patterns of bacterivory by flagellates, ciliates, rotifers, and cladocerans in a freshwater planktonic community. Limnol Oceanogr 34:673-687

Sherr BF, Sherr EB, Berman T (1983) Grazing, growth and ammonium excretion rates of a heterotrophic microflagellate fed by four species of bacteria. Appl Environ Microbiol 45:1196-1201

Sherr BF, Sherr EB, Rassoulzadegan F (1988) Rates of digestion of bacteria by marine phagotrophic protozoa: temperature dependence. Appl Environ Microbiol 54:1091-1095

Sherr EB, Sherr BF (1993) Protistan grazing rates via uptake of fluorescently labelled prey. In: Kemp P, Sherr BF, Sherr EB, Cole J (eds) Handbook of methods in aquatic microbial ecology. Lewis Publishers, Boca Raton, FL, p 695-701

Sherr EB, Sherr BF (2002) Significance of predation by protists in aquatic microbial food webs. Antonie Leeuwenhoek 81:293-308

Editorial responsibility: David Caron,

Los Angeles, California, USA
Šimek K, Hartman P, Nedoma J, Pernthaler J, Vrba J, Springmann D, Psenner R (1997) Community structure, picoplankton grazing and zooplankton control of heterotrophic nanoflagellates in a eutrophic reservoir during the summer phytoplankton maximum. Aquat Microb Ecol 12: $49-63$

Šimek K, Macek M, Sed'a J, Vyhnálek V (1990) Possible food chain relationships between bacterioplankton, protozoans, and cladocerans in a reservoir. Int Rev Gesamten Hydrobiol 75:583-596

Šimek K, Jürgens K, Nedoma J, Comerma M, Armengol J (2000) Ecological role and bacterial grazing of Halteria spp.: small oligotrichs as dominant pelagic ciliate bacterivores. Aquat Microb Ecol 22:43-56

Šimek K, Horňák K, Mašín M, Christaki U, Nedoma J, Weinbauer MG, Dolan JR (2003) Comparing the effects of resource enrichment and grazing on a bacterioplankton community of a meso-eutrophic reservoir. Aquat Microb Ecol 31:123-135

Sommaruga R, Psenner R (1993) Nanociliates of the order Prostomatida: their relevance in the microbial food web of a mesotrophic lake. Aquat Sci 55:179-187

Sonntag B, Posch T, Psenner R (2000) Comparison of three methods for determining flagellate abundance, cell size, and biovolume in cultures and natural freshwater samples. Arch Hydrobiol 149:337-351

Stell RGD, Torrie JH (1980) Principles and procedures of statistics, 2nd edn. McGraw-Hill, New York

Vaqué D, Pace ML (1992) Grazing on bacteria by flagellates and cladocerans in lakes of contrasting food-web structure. J Plankton Res 14:307-321

Vaqué D, Gasol JM, Marrasé C (1994) Grazing rates on bacteria: the significance of methodology and ecological factors. Mar Ecol Prog Ser 109:263-274

Weisse T (1991) The annual cycle of heterotrophic freshwater nanoflagellates: role of bottom-up versus top-down control. J Plankton Res 13:167-185.

Weisse T (2002) The significance of inter- and intraspecific variation in bacterivorous and herbivorous protists. Antonie Leeuwenhoek 81:327-341

Submitted: October 3, 2003; Accepted: March 8, 2004 Proofs received from author(s): August 2, 2004 